\section{Edrophonium require- ments for reversal of deep neuromuscular block following infusion of mivacurium}

Donald R. Miller MD, Gregory Bryson MD,

Raymond J. Martineau MD, John B. Kitts MD,

Michael Curran MD, Paul Bragg MD,

John B. Watson MD, Kathryn Hull RN,

Patrice Lindsay RN.
Mivacurium is a new non-depolarizing muscle relaxant consisting of three stereoisomers. The two active isomers (cis-trans and trans-trans) undergo rapid metabolism by plasma cholinesterase $\left(t_{1 / 2} \beta<2 \mathrm{~min}\right)$. Due to its rapid elimination, the need for reversal of mivacurium-induced neuromuscular block is controversial, and to date there have been no studies evaluating reversal of deep blocks. The object of the current investigation was to establish the lowest effective dose of edrophonium required to reverse deep mivacurium-induced neuromuscular block. One hundred ASA Class I and II patients undergoing outpatient surgery in two teaching institutions were studied in this randomized, placebo-controlled double-blind trial. Under balanced propofol/nitrous oxide/alfentanil anaesthesia, a continuous infusion of mivacurium was adjusted to maintain between 5-10\% of control $T_{1}$ amplitude. Upon completion of surgery, neuromuscular block was reversed by injecting normal saline (Group PLAC), edrophonium $0.125 \mathrm{mg} \cdot \mathrm{kg}^{-1}$ (Group EDR-1), $0.25 \mathrm{mg} \cdot \mathrm{kg}^{-1}$ (Group EDR-2), or $0.50 \mathrm{mg} \cdot \mathrm{kg}^{-1}$ (Group EDR-3), in addition to a corresponding dose of atropine. Spontaneous recovery, from a $T_{1}$ response of $<10 \%$ to a TOF ratio $\geq 0.7$, required $13.5 \pm 2.6 \mathrm{~min}$ (PLAC Group). In comparison, patients in the EDR-1 group required $9.2 \pm$ $2.6 \mathrm{~min}(P<0.01)$. Higher doses of edrophonium conferred no advantage. Four patients (4\%) had not achieved a TOF

\section{Key words}

NEUROMUSCULAR RELAXANTS: mivacurium; ANTAGONISTS: anticholinesterase, edrophonium; MONTTORING: electromyography.

From the Departments of Anaesthesia, Ottawa General Hospital, Ottawa Civic Hospital, and the University of Ottawa.

Presented in part at the 51st Annual Meeting of the Canadian Anaesthetists' Society, Edmonton, Alberta, June 1994.

Supported by a Research Grant from Burroughs-Wellcome, Canada Inc.

Address correspondence to: Dr. Donald R. Miller, Department of Anaesthesia, Ottawa General Hospital, 501

Smyth Road, Ottawa, Ontario K1H 8L6.

Accepted for publication 16th Jume, 1995. ratio of $\geq 70 \%$, 20 min after reversal, and required additional edrophonium. Two patients (PLAC group), had dibucaine numbers and cholinesterase levels consistent with an $E^{U} E^{A}$ genotype, whereas the two patients with delayed recovery in the EDR-I group had characteristics of a normal genotype. We conclude that a very low dose of edrophonium $\left(0.125 \mathrm{mg} \cdot \mathrm{kg}^{-1}\right)$ hastens reversal of deep mivacurium-induced neuromuscular block by approximately four minutes, and that edrophonium doses exceeding $0.125 \mathrm{mg} \cdot \mathrm{kg}^{-1}$ provide no additional benefit. Heterozygous patients with atypical plasma cholinesterase levels, as well as certain individuals with normal dibucaine numbers and plasma cholinesterase activity, are at risk for prolonged neuromuscular block, but the block is easily reversed with edrophonium.

Le mivacurium est un nouveau relaxant musculaire non dépolarisant constitué de trois isomères. Les dewx isomères actifs (cis-trans et trans-trans) sont métabolisés rapidement par la cholinestérase plasmatique $\left(t_{1 / 2} \beta<2 \mathrm{~min}\right)$. A cause de l'élimination rapide, la nécessité de neutraliser le bloc neuromusculaire induit par le mivacurium est sujette à controverse, et, jusqu'à maintenant, on n'a pas réalisé d'études portant sur la neutralisation de la curarisation pnofonde. L'objet de l'étude présente était d'établir la dase efficace d'édrophonium la plus faible requise pour neutraliser la curarisation profonde induite par le mivacurium. Cent patients ASA I et II subissant une chirurgie ambulatoire dans deux hôpitaux d'enseignement font partie de cette étude randomisée à double insu avec contrôle par placebo. Sous anesthésie équilibrée au propofol/protoxyde d'azote/alfentanil, une perfusion continue de mivacurium est réglée de façon à maintenir l'amplitude de $T_{l}$ à S-10\% du contrôle. Après lintervention, la curarisation est traitée avec une injection de soluté physiologique (groupe PLAC), d'édrophonium, 0,125 $\mathrm{mg} \cdot \mathrm{kg}^{-1}$ (Groupe EDR-1), 0,25 $\mathrm{mg} \cdot \mathrm{kg}^{-1}$ (Groupe EDR-2), ou $0,50 \mathrm{mg} \cdot \mathrm{kg}^{-1}$ (Group EDR-3), avec l'addition diune dose appropriée d'atropine. Le récupération spontanée, diun $T_{l}$ de $10 \%$ jusqu'à un rapport au TOF $\geq 0,7$, a nécessité 13,5 $\pm 2,6$ min (Groupe $P L A C$ ). En comparaison, les patients du groupe $E D R-1$ ont eu besoin de 9,2 $\pm 2,6 \min (P<0,01)$. Les dases plus importantes d'édrophonium ne procurent pas d'avantage. 
Quatre patients (4\%) n'ont pas atteint un rapport au TOF $\geq 70 \%$ 20 min après la neutralisation et ont eu besoin d'édrophonium supplémentaire. Deux patients (groupe $P L A C$ ) avaient un index de dibucaïne et des niveaux de cholestérol compatibles avec un génotype $E^{U} E^{A}$, alors que deux des patients dont la récupération était retardée dans le groupe EDR-I avaient des caractéristiques génétiques normales. Les auteurs concluent quiune très faible dose d'édrophonium $\left(0,125 \mathrm{mg} \cdot \mathrm{kg}^{-1}\right)$ accélère la neutralisation du bloc neuromusculaire profond au mivacurium par environ quatre minutes, et que l'édrophonium en doses supérieures à $0,125 \mathrm{mg} \cdot \mathrm{kg}^{-I}$ ne procure pas de bénéfices additionnels. Les hétérozygotes avec des niveaux de cholinestérase plasmatique atypique, ainsi que certains individus possédant des index de dibucaüne normaux et une activité cholinestérasique normale, sont à risque d'ine curarisation prolongée qui peut être toutefois neutralisée facilement avec de l'édrophonium.

Mivacurium hydrochloride is a new non-depolarizing muscle relaxant which has been available for clinical use in Canada since 1994. The clinical advantages of this unique drug are attributable to its remarkably short recovery time, due to rapid metabolism by plasma cholinesterase ${ }^{1,2}$ and its low potential for cumulation. ${ }^{3}$ Following "intubating" doses of mivacurium, it requires only 25-30 $\mathrm{min}$ for the train-of-four ratio to recovery spontaneously to $>0.7 .{ }^{4}$ Recently, it has been suggested that recovery from mivacurium may be prolonged to a certain extent when larger doses are administered, or when the drug is administered by continuous infusion. ${ }^{5}$ This can be explained by the fact that when administering higher doses or infusions of non-depolarizing relaxants, recovery depends to a greater extent on elimination than on redistribution processes. 6 However, such differences are thought to be of minimal clinical importance with mivacurium, as the elimination half-life of the two active stereoisomers (cis-trans and trans-trans) undergo rapid metabolism by plasma cholinesterase $\left(\mathrm{t}_{1 / 2} \beta<2 \mathrm{~min}\right) .^{1}$

Reflecting this unique pharmacological profile, considerable debate has arisen regarding the need for, and optimal dose of, anticholinesterase medication for reversal of mivacurium-induced neuromuscular block. A previous study has shown that the duration of recovery from mivacurium decreases by only four minutes after a full reversal dosage of neostigmine. ${ }^{7}$ However, as neostigmine's peak nicotinic effects occur well into the spontaneous recovery phase of mivacurium-induced block, neostigmine may not be the optimal reversal agent for this drug. In fact, it has even been shown that neostigmine may prolong complete recovery from mivacurium when the level of block is deep, possibly due to plasma cholinesterase inhibition. ${ }^{8}$ Edrophonium, in contrast, achieves peak ni- cotinic effects within one-two minutes. ${ }^{9}$ Accordingly, the rapid onset of action of edrophonium may provide a more appropriate temporal response for antagonism of mivacurium. ${ }^{10}$ For these reasons, a study was undertaken to determine the dose-response relationship of edrophonium for reversal of deep neuromuscular block following a continuous infusion of mivacurium, in healthy day-care surgery patients. In view of the relative novelty of this muscle relaxant, a secondary objective was to determine infusion requirements and side effects of mivacurium in this outpatient population.

\section{Methods}

\section{Study population}

This randomized, double-blind study was conducted at two university-affiliated adult hospitals, of the same medical faculty. The sample size of $n=100$ was calculated by determining the total number of subjects required to detect a difference in recovery time of three minutes, assuming an $\alpha=0.05$, and $1-\beta=0.9$. Subjects of either sex, ASA class I or II and between 18-60 yr of age, entered the study after giving written informed consent to the protocol approved by the Research Ethics Boards of both institutions. All subjects were day care patients undergoing either elective general, orthopaedic, or gynaecological surgery, scheduled to last between $30-90 \mathrm{~min}$. The following criteria resulted in exclusion from the study: any symptom or sign of neurological or neuromuscular disease; current or chronic use of drugs known to interact with muscle relaxants (dilantin, aminoglycosides); history or laboratory evidence of hepatic or renal insufficiency; or a generally compromised medical status (ASA physical status Class III, IV or V). An abnormal body mass index, defined as $\mathrm{BMI}<20 \mathrm{~kg} \cdot \mathrm{m}^{-2}$ or $>30 \mathrm{~kg} \cdot \mathrm{m}^{-2}$, and pregnancy, also resulted in exclusion.

\section{Anaesthetic technique}

Consistent with established surgical day care procedures at both study institutions, patients were unpremedicated. Following application of routine anaesthetic monitors, and insertion of an $18 \mathrm{G}$ peripheral intravenous cannula, patients received midazolam $0.03 \mathrm{mg} \cdot \mathrm{kg}^{-1} i \mathrm{v}$ for sedation. Alfentanil $20-30 \mu \mathrm{g} \cdot \mathrm{kg}^{-1} \dot{i \nu}$ was then given over a period of $60 \mathrm{sec}$, followed by a continuous infusion at a rate of $1.0 \mu \mathrm{g} \cdot \mathrm{kg}^{-1} \cdot \mathrm{min}^{-1}$, while patients breathed $100 \% \mathrm{O}_{2}$. Induction of anaesthesia then proceeded with propofol $1.5-2.0 \mathrm{mg} \cdot \mathrm{kg}^{-1}$, titrated to loss of consciousness. Control valves to supramaximal stimuli from the EMG monitor were established, after which mivacurium $0.15 \mathrm{mg} \cdot \mathrm{kg}^{-1}$ was given, followed by a continuous infusion of the drug. When the $T_{1}$ value had decreased to $<10 \%$ of the control amplitude, the patient's airway 
was secured with an oral endotracheal tube of appropriate size, under direct laryngoscopy. Anaesthesia was subsequently maintained with $70 \%$ nitrous oxide in oxygen, with minute ventilation controlled to achieve an end-tidal PETCO $_{2}$ between $30-35 \mathrm{mmHg}$. Variable rate infusions of propofol and alfentanil were administered, and adjusted to maintain heart rate and blood pressure within $20 \%$ of each patient's normal, awake values. During the period of reversal, alfentanil and propofol infusions were discontinued, while anaesthesia was maintained with unsupplemented $\mathrm{N}_{2} \mathrm{O} / \mathrm{O}_{2}$, until the time of complete reversal. Throughout the study, potent inhalational agents were precluded, to avoid their potentiating effects on the depth of the mivacurium-induced neuromuscular block.

\section{Mivacurium: infusion and reversal protocol}

A programmable intravenous syringe pump was used to control the infusion of mivacurium, beginning at a rate of $5.0 \mu \mathrm{g} \cdot \mathrm{kg}^{-1} \cdot \mathrm{min}^{-1}$. Throughout surgery, the rate of infusion was adjusted as required, in increments or decrements of $10 \%$, to maintain the $\mathrm{T}_{1}$ amplitude between $5-10 \%$ of control. The relatively deep degree of neuromuscular block was targeted to ensure adequate relaxation for surgery, while simultaneously allowing for the possibility of patient movement in response to light levels of anaesthesia. Subsequent adjustments in the infusion rate were made at intervals no more frequently than five minutes, in order to provide a period of stabilization of drug effect following each rate adjustment of the muscle relaxant.

Toward the end of surgery, the infusion of mivacurium was discontinued when deemed clinically appropriate. To ensure between-groups comparability with regard to the depth of neuromuscular block at the time of reversal, the coded reversal medication was administered immediately upon termination of the mivacurium infusion, without allowing for any spontaneous recovery. Reversal consisted of either normal saline, or one of three doses of edrophonium plus atropine, given $i v$ over $30 \mathrm{sec}$. Blinding was achieved by delivering reversal medications from a coded $10 \mathrm{ml}$ syringe, in a weight-adjusted volume of 0.1 $\mathrm{ml} \cdot \mathrm{kg}^{-1}$, according to the following group assignments:

Group PLAC: Normal saline (placebo)

Group EDR-1: Edrophonium $0.125 \mathrm{mg} \cdot \mathrm{kg}^{-1}+$ atropine $0.002 \mathrm{mg} \cdot \mathrm{kg}^{-1}$

Group EDR-2: Edrophonium $0.250 \mathrm{mg} \cdot \mathrm{kg}^{-1}+$ atropine $0.004 \mathrm{mg} \cdot \mathrm{kg}^{-1}$

Group EDR-3: Edrophonium $0.500 \mathrm{mg} \cdot \mathrm{kg}^{-1}+$ atropine $0.008 \mathrm{mg} \cdot \mathrm{kg}^{-1}$

Patients had an equal probability of being assigned to one of the four treatment groups, according to a computer-generated randomization schedule. Allocation concealment was achieved with the use of sealed envelopes.

The possibility of studying patients with undiagnosed atypical plasma cholinesterase activity was taken into consideration by identifying the following criteria as an abnormal response to mivacurium:

1 maintaining complete abolition of the first twitch response for $>15 \mathrm{~min}$ following the loading dose of mivacurium, or

2 failing to achieve a $T_{4}$ ratio $>0.7$ within $20 \mathrm{~min}$ of administration of the reversal drugs.

Such individuals received a supplemental dose of edrophonium $0.5 \mathrm{mg} \cdot \mathrm{kg}^{-1} /$ atropine $0.008 \mathrm{mg} \cdot \mathrm{kg}^{-1}$ (as a "rescue"), while continuing to monitor the level of neuromuscular block until complete reversal. For any patient who required "rescue" medication, testing for atypical plasma cholinesterase activity was performed by taking blood samples for determination of cholinesterase activity and dibucaine number.

\section{Measurements}

The primary outcome measure in this study was the time required to achieve a TOF ratio $\geq 0.7$ following administration of reversal medication. This was evaluated by measuring the depth of neuromuscular block during the infusion of mivacurium, and following reversal, using an integrated evoked electromyogram (EMG). The EMG was calibrated prior to induction of anaesthesia, after which supramaximal train-of-four (TOF) stimuli, at impulses of $0.2 \mathrm{msec}$ duration and a frequency of $2 \mathrm{~Hz}$, were recorded every $20 \mathrm{sec}$ with a Datex (i) 221 NMT Relaxograph monitor. Supramaximal stimuli were applied to the ulnar nerve using skin electrodes, and the evoked electromyogram was recorded over the first dorsal interosseous muscle. In addition to the continuous TOF response, the following data were recorded: time to onset of $90 \% \mathrm{~T}_{1}$ suppression; $\% \mathrm{~T}_{1}$ suppression during and at the end of the mivacurium infusion; and once the infusion was terminated, time for the train-of-four ratio to recover to a value $\geq 70 \%$. Also, using a Critikon 1846 Vital Signs Monitor ${ }^{\circ}$, heart rate and systolic blood pressures were recorded at one minute intervals for five minutes, following administration of the loading dose of mivacurium, and at five minute intervals thereafter during the course of the infusion. The skin about the torso and head and neck were inspected by the research nurse, for the presence or absence of swelling and erythema, at the same time as the cardiovascular variables were recorded.

\section{Statistical analysis}

Data were analyzed using repeated measures analysis of variance (ANOVA) to compare mivacurium requirements among groups, during the course of infusion. Recovery 
times were compared using ANOVA and Fischer's exact test, with Bonferroni correction. Data are presented as mean \pm standard deviation, as well ranges were appropriate, throughout the text, figures and tables. Statistical significance was assumed when $P \leq 0.05$.

\section{Results}

One hundred and seven patients entered the study, of whom seven were excluded either due to technical difficulties with the infusion, or because of an inability to maintain a consistent EMG signal. Of the remaining 100 subjects who completed the protocol, two in the PLAC group were subsequently found to have laboratory variables consistent with $\mathrm{E}^{\mathrm{U}} \mathrm{E}^{\mathrm{A}}$ genotype, requiring their EMG data to be analyzed separately. Demographic characteristics were similar in all groups (Table I). Patients underwent either general surgery, gynaecological surgery, or orthopaedic surgery, without clinically important adverse surgical or anaesthetic sequelae.

\section{Mivacurium infusion characteristics}

The mean duration of mivacurium infusion was <one hour in all four groups (mean values 44.9 $\pm 20.8-49.3$ $\pm 19.3 \mathrm{~min}$, range $=30-92 \mathrm{~min}$, Table II). A considerable number of adjustments were required in most patients in order to maintain the desired depth of neuromuscular block, but mean rates (between $4.4 \pm 2.0$ to $5.2 \pm 2.3$ $\mu \mathrm{g} \cdot \mathrm{kg}^{-1} \cdot \mathrm{min}^{-1}$ ) were not different among groups at corresponding times during the course of infusion. Thirtysix patients (36\%) experienced a transient hypotensive response, defined as a decrease in systolic blood pressure (SBP) to $<90 \mathrm{mmHg}$, or a decrease of SBP $>30 \%$ of the pre-induction value. This was associated with induction of anaesthesia, and occurred within the first five minutes of administration of the loading (intubating) dose of mivacurium. Six patients $(6 \%)$ developed cutaneous flushing about the head and neck, which was considered to have been either possibly or probably related to the muscle relaxant administration in all cases. Importantly, however, signs of hypotension and flushing resolved spontaneously in every affected individual without recurrence, and without requiring specific treatment or intervention.

\section{Spontaneous recovery vs edrophonium reversal}

According to study design, titration of the mivacurium infusion resulted in similar levels of neuromuscular block at the time of reversal (Table II). From this relatively deep level of paralysis $\left(T_{1}<10 \%\right), 13.5 \pm 3.1 \mathrm{~min}$ were required for the $\mathrm{T}_{4}$ ratio to recovery spontaneously to $\geq 0.7 \%$ (PLAC group). In contrast, mean recovery times were shorter in all three groups when the bock was reversed with edrophonium (9.2 $\pm 2.6 \mathrm{~min}$ EDR-1; 9.4 $\pm 2.0 \mathrm{~min}$ EDR-2; $9.2 \pm 3.3 \mathrm{~min}$ EDR-3) when com-
TABLE I Patient characteristics

\begin{tabular}{lllll}
\hline Group & $\begin{array}{l}P L A C \\
(n=25)\end{array}$ & $\begin{array}{l}\text { EDR-1 } \\
(n=25)\end{array}$ & $\begin{array}{l}\text { EDR-2 } \\
(n=25)\end{array}$ & $\begin{array}{l}\text { EDR-3 } \\
(n=25)\end{array}$ \\
\hline Age (yr) & $34 \pm 9$ & $35 \pm 10$ & $38 \pm 12$ & $35 \pm 8$ \\
Weight (kg) & $69 \pm 12$ & $71 \pm 8$ & $72 \pm 16$ & $70 \pm 11$ \\
Sex (m/f) & $10 / 15$ & $13 / 12$ & $10 / 15$ & $8 / 17$ \\
ASA Class (I/II) & $18 / 7$ & $17 / 8$ & $19 / 6$ & $22 / 3$ \\
\hline
\end{tabular}

Values are mean $\pm S D$.

TABLE II Mivacurium recovery characteristics

\begin{tabular}{|c|c|c|c|c|}
\hline Group & $\begin{array}{l}P L A C \\
(n=25)\end{array}$ & $\begin{array}{l}E D R-1 \\
(n=25)\end{array}$ & $\begin{array}{l}E D R-2 \\
(n=25)\end{array}$ & $\begin{array}{l}E D R-3 \\
(n=25)\end{array}$ \\
\hline $\begin{array}{l}\text { Infusion duration } \\
\text { (min) }\end{array}$ & $49.3 \pm 19.3$ & $46.1 \pm 19.3$ & $49.6 \pm 24.0$ & $44.9 \pm 20.8$ \\
\hline $\begin{array}{l}\mathrm{T}_{1 \text { rew }} \text { (\% control) } \\
\text { Recovery times }\end{array}$ & $5.5 \pm 2.5$ & $6.5 \pm 2.5$ & $5.6 \pm 2.4$ & $5.9 \pm 2.3$ \\
\hline$(\min )$ & $13.5 \pm 3.1$ & $9.2 \pm 2.6^{*}$ & $9.4 \pm 2.0^{*}$ & $9.2 \pm 3.3^{*}$ \\
\hline
\end{tabular}

$* P<0.01$, different from PLAC.

Values are mean $\pm S D$ (range in parentheses). $T_{1 \text { rev }}=T_{1}$ amplitude at time of administration of reversal drug.

pared with PLAC $(P<0.001$, Table II). The dispersion of recovery time data are well represented in the accompanying Tukey plot (Figure). Remarkably, no differences in recovery times were observed when comparing the three edrophonium groups, despite a four-fold gradation in the weight-adjusted dose of this anticholinesterase drug.

\section{Cases of prolonged recovery}

Four of the 100 patients (4\%) demonstrated heightened sensitivity to the effects of mivacurium, as initially suspected by prolonged abolition of the twitch response following the loading dose. This required a temporary interruption of the muscle relaxant infusion to allow recovery of the $T_{1}$ amplitude to a value between 5-10\%. All four subjects required "rescue medication," following which prompt reversal ensued within the next two minutes. Two of these subjects were in the PLAC group, and two were in the EDR-1 group (Table III). Subsequent determination of plasma cholinesterase activity and dibucaine testing revealed that both patients in the PLAC group had patterns consistent with an $\mathrm{E}^{\mathrm{U}} \mathrm{E}^{\mathrm{A}}$ genotype. Of interest, however, laboratory data of the two patients with a prolonged recovery in the EDR-1 group indicated normal variables, reflective of an $\mathrm{E}^{\mathrm{U}} \mathrm{E}^{\mathrm{U}}$ genotype (Table III).

\section{Discussion}

Since the introduction of mivacurium to clinical anaes- 


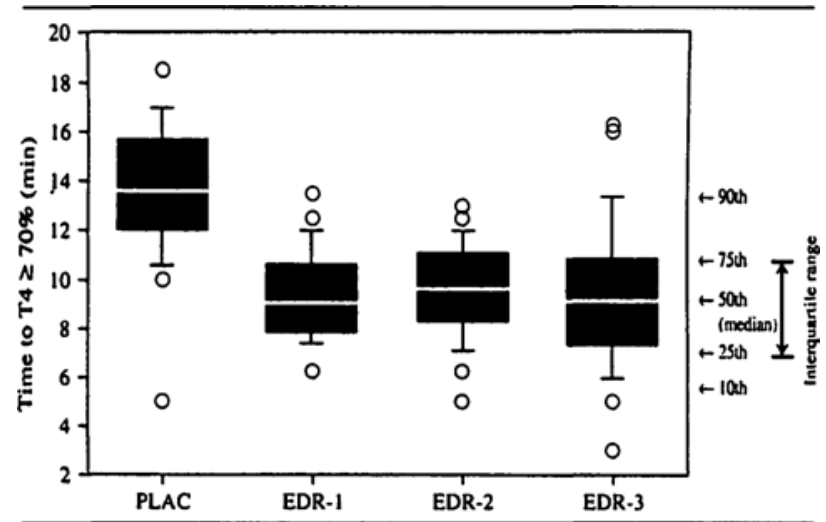

FIGURE A tukey (box plot) displaying the 10th, 25th, 50th, 75th and 90th percentiles of the times required for $T_{4}$ response to achieve an amplitude $>70 \%$ for control following administration of reversal, for each of the four groups (PLAC = edrophonium $0.0 \mathrm{mg} \cdot \mathrm{kg}^{-1}$ placebo; EDR-1 = edrophonium $0.125 \mathrm{mg} \cdot \mathrm{kg}^{-1}$; EDR-2 $=0.25$ $\mathrm{mg} \cdot \mathrm{kg}^{-1} ; \mathrm{EDR}-3=0.50 \mathrm{mg} \cdot \mathrm{kg}^{-1}$ ). Values $<10$ th and $>90$ th percentiles are displayed separately, to reflect the range of values. Recovery times were reduced to a similar extent in all three EDR groups compared with PLAC.

thesia in the United States (1992) and Canada (1994), the drug's unique recovery profile as a non-depolarizing muscle relaxant has resulted in the practice of avoiding routine reversal of residual block, once signs of spontaneous recovery are apparent. This practice may be justified by the fact that only modest decreases in recovery time are observed, when reversal is assisted with either edrophonium or neostigmine. ${ }^{7,10}$ However, due to recognized limitations in using a peripheral nerve stimulator to determine recovery of neuromuscular function, ${ }^{11,12}$ and in situations where the level of neuromuscular block is relatively deep at the end of surgery, it is important to know the appropriate dose of anticholinesterase drug for reversal of mivacurium. For these reasons, the current study was undertaken, which convincingly demonstrates that: (1) antagonism with edrophonium decreases recovery time by approximately four minutes when the $T_{1}$ amplitude at reversal is $<10 \%$ and, (2) there is no clinical advantage in using a dose of edrophonium exceeding $0.125 \mathrm{mg} \cdot \mathrm{kg}^{-1}$.

These findings support and expand upon several aspects of a recent study by Kopman et al..$^{10}$ In that study, 58 patients received a continuous infusion of mivacurium, before randomizing subjects to either spontaneous recovery, or to reversal with one of three doses of edrophonium $\left(0.3,0.5\right.$, or $\left.0.75 \mathrm{mg} \cdot \mathrm{kg}^{-1}\right)$. An apparent methodological difference in comparing these studies is that the Kopman group measured recovery times to TOF. values of 0.7 and 0.9 from a subjective end-point (train-of-four count), while allowing a degree of spontaneous recovery to occur prior to reversal. These investigators observed that ad-
TABLE III Prolonged responses to mivacurium

\begin{tabular}{|c|c|c|c|c|}
\hline Characteristic/patient no. & 017 & 083 & 022 & 050 \\
\hline Group & PLAC & PLAC & EDR-1 & EDR-1 \\
\hline $\begin{array}{l}\text { Time for } T_{1} \text { to return after } \\
\text { intubating dose ( } \mathrm{min})\end{array}$ & 30 & 31 & 37 & 18 \\
\hline $\mathrm{T}_{1}$ at reversal (\% control) & 6 & 2 & 1 & 6 \\
\hline $\begin{array}{l}\mathrm{T}_{4} \text { ratio (\%) at time of "rescue" } \\
(20 \text { min post-reversal) }\end{array}$ & 47 & 60 & 62 & 61 \\
\hline $\begin{array}{l}\text { Time to } \mathrm{T}_{4} \text { ratio }>70 \% \text { after } \\
\text { "rescue" }(\mathrm{min})\end{array}$ & 1.3 & 2.0 & 1.7 & 0.7 \\
\hline $\begin{array}{l}\text { Dibucaine Number }(\%) \\
\text { (Normal }=81-86 \% \text { INH) }\end{array}$ & $76^{*}$ & $79^{*}$ & 83 & 81 \\
\hline $\begin{array}{l}\text { Plasma Cholinesterase }(\mathrm{KU} / \mathrm{L}) \\
\text { (Normal }=4.8-12.0 \mathrm{KU} / \mathrm{L}) \\
\text { Genotype }\end{array}$ & $\begin{array}{r}4.3^{*} \\
\mathbf{E}^{U^{\mathrm{U}}} \mathrm{E}^{\mathrm{A}}\end{array}$ & $\begin{array}{r}4.5^{*} \\
E^{U} E^{A}\end{array}$ & $\begin{array}{c}5.5 \\
\mathbf{E}^{U^{U}}\end{array}$ & $\begin{array}{c}6.1 \\
E^{U_{E^{U}}}\end{array}$ \\
\hline
\end{tabular}

Phenotypes and genotypes of four patients $(4 / 100=4 \%)$, who experienced a delay in recovery following termination of the mivacurium infusion. $\mathrm{E}^{\mathrm{U}} \mathrm{E}^{\mathrm{U}}=$ normal genotype for plasma cholinesterase; $E^{U} E^{A}=$ atypical genotype for plasma cholinesterase activity.

*abnormal result.

ministration of $0.3 \mathrm{mg} \cdot \mathrm{kg}^{-1}$ edrophonium decreased recovery time by approximately $7.5 \mathrm{~min}$ and, consistent with our findings, higher doses of edrophonium conferred no greater speed of recovery. In addition to the blinding technique, an important distinguishing feature of our work is that the lowest dose of edrophonium was less than half the lowest effective dose of edrophonium in the Kopman study $\left(0.125 \mathrm{mg} \cdot \mathrm{kg}^{-1}\right.$ vs $\left.0.3 \mathrm{mg} \cdot \mathrm{kg}^{-1}\right)$. It is also remarkable that our findings occurred when reversal medication was given at the end of the mivacurium infusion, without having allowed for any spontaneous recovery.

The extent to which the dose of edrophonium can be reduced to antagonize mivacurium-induced neuromuscular block is clinically relevant for two main reasons. First, the absence of a detectable dose-response relationship in reversal requirements, beyond a dose of $0.125 \mathrm{mg} \cdot \mathrm{kg}^{-1}$, would suggest that current recommendations for reversal of intermediate duration and long-acting relaxants may require modification for mivacurium. Based on the response to train-of-four stimulation, Bevan et al. ${ }^{13}$ recommend an edrophonium dose between $0.25-0.50$ $\mathrm{mg} \cdot \mathrm{kg}^{-1}$ when four visible twitches are present, and there is little evidence of fade. ${ }^{13}$ Results from the current study demonstrate that following an infusion of mivacurium, only half this amount of edrophonium is required, even in the presence of a much deeper level of block. Of equal importance, and based on the similarity of recovery times as well as the ranges of recovery times, there is no evidence to suggest that using a larger dose of edrophonium confers any greater margin of safety with re- 
gard to the incidence of residual neuromuscular block following mivacurium, in patients with normal plasma cholinesterase activity. This can be accounted for by the rapid spontaneous recovery profile of this short-acting neuromuscular blocking drug, when compared with either atracurium, vecuronium, or rocuronium.

A second potential advantage to using low doses of edrophonium (approximately $10 \mathrm{mg} \cdot 70 \mathrm{~kg}^{-1}$ patient) for reversal of mivacurium, is related to pharmacoeconomic considerations. Although these were not specifically addressed in the current study, it is easy to estimate that the direct cost-saving for reversal would be approximately $\$ 1.25$ /patient, when comparing an edrophonium dose of $0.125 \mathrm{mg} \cdot \mathrm{kg}^{-1}$ vs a "standard" dose of $0.5 \mathrm{mg} \cdot \mathrm{kg}^{-1}$ for a $70 \mathrm{~kg}$ individual. This difference, although relatively trivial on a per-case basis, could amount to savings of several thousands of dollars per year in a busy surgical suite. Of potentially greater importance, however, are the possible indirect economic benefits which could result from lowering the dose of anticholinesterase drug, as neostigmine, and to a lesser extent edrophonium, have been associated with an increased incidence of postoperative nausea and vomiting. ${ }^{14,15}$ Due to the potential influence of a number of confounding variables, a large-scale study would be in order to address this particular issue.

A final matter to consider regarding reversal requirements of mivacurium-induced neuromuscular block is the response of edrophonium in patients who have atypical plasma cholinesterase activity, or one of its variants. Consistent with the results of other studies in normal individuals, ${ }^{1}$ it was found that the time required for spontaneous recovery from a $T_{1}$ level at $5 \%$ of control was approximately $14 \mathrm{~min}$ following infusion of mivacurium. However, two patients in the PLAC group developed complete abolition of the $T_{1}$ response shortly after administration of the loading dose of mivacurium, which persisted for at least ten minutes, and was associated with rapidly decreasing drug requirements during the period of infusion. Both patients received "rescue medication," consisting of a larger dose of edrophonium $0.5 \mathrm{mg} \cdot \mathrm{kg}^{-1}$, administered at an interval not less than $20 \mathrm{~min}$ after the infusion was terminated. This resulted in recovery of neuromuscular function in both individuals in < two minutes. Subsequent determination of dibucaine numbers and plasma cholinesterase activity was reflective of an $\mathrm{E}^{\mathrm{U}} \mathrm{E}^{\mathrm{A}}$ genotype in both patients. Accordingly, recovery data for these two persons were not included in the mean values for PLAC group.

The observation of two patients in 100 (2\% incidence) who exhibited atypical plasma cholinesterase activity is consistent with the knowledge that in Caucasian populations, the frequency of heterozygotes for the normal and atypical genes is normally about 1 in $25(4 \%)$, and the frequency of homozygotes for the atypical gene is about 1 in $2500 .{ }^{16,17}$ of greater interest, however, was the observation of two patients in the EDR-1 group who demonstrated a similarly profound response to the initial dose of mivacurium, but had normal dibucaine numbers and plasma cholinesterase activity on subsequent analysis. As these patients were genotypically "normal" acconding to current laboratory testing, their data were included in the means of their group. It is possible that errors in laboratory testing could account for the discrepancies. More likely, however, is the possibility that the dibucaine numbers and plasma cholinesterase values failed to identify variants of this enzyme.

Recently, the application of molecular genetics has permitted precise identification of plasma cholinesterase variants, and has resulted in the discovery of at least 20 mutations in the coding region of the plasma cholinesterase gene. ${ }^{18}$ Other recent work has demonstrated that plasma cholinesterase variants exist which can be identified by using only succinylcholine as the substrate, rather than the traditionally employed substrates: benzycholine, butyrylcholine, or their respective thio-esters. ${ }^{19}$ This would suggest that some plasma cholinesterase variants have probably failed detection through use of surrogate markers, and that people with a history of prolonged response to mivacurium (or succinylcholine) should undergo such additional testing procedures. However, a lack of available testing centres will preclude widespread use of these procedures for at least the next several years. Fortunately, variations in plasma cholinesterase activity, including values as low as $20 \%$ below the limits of the normal range, tend not to be associated with a clinically important influence on the duration of mivacurium's effects, although greater variability in the drug's duration of action may be apparent. ${ }^{16}$ In contrast, patients with the homozygous atypical genotype will experience great prolongations in block following administration of mivacurium, as they would following administration of succinylcholine.

In conclusion, this study has demonstrated that a very low dose of edrophonium $\left(0.125 \mathrm{mg} \cdot \mathrm{kg}^{-1}\right)$ hastens reversal of deep mivacurium-induced neuromuscular block by approximately four minutes, and that edrophonium doses exceeding $0.125 \mathrm{mg} \cdot \mathrm{kg}^{-1}$ provide no additional benefit. Heterozygous patients with atypical plasma cholinesterase levels, as well as certain individuals with normal dibucaine numbers and plasma cholinesterase activity, are at risk for prolonged neuromuscular block, but the block is easily reversed with edrophonium.

\section{Acknowledgments}

The authors express their sincere gratitude to the operating room nurses and surgeons of the Ottawa General 
and Ottawa Civic Hospitals, whose patience and cooperation throughout made these studies possible. The special efforts of Dr. Nick Cicutti, in assisting with data analysis, are also gratefully acknowledged.

\section{References}

1 Lien CA, Schmith VD, Embree PB, Belmont MR, Wargin $W A$, Savarese JJ. The pharmacokinetics and pharmacodynamics of the stereoisomers of mivacurium in patients receiving nitrous oxide/opioid/barbiturate anesthesia. Anesthesiology 1994; 80: 1296-302.

2 Cook DR, Stiller RL, Weakly JN, Chakravorti S, Brandom $B W$, Welch $R M$. In vitro metabolism of mivacurium chloride (BW B1090U) and succinylcholine. Anesth Analg 1989; 68: 452-6.

3 Diefenbach $C$, Mellinghoff $H$, Lynch J, Buzello $W$. Mivacurium: dose-response relationship and administration by repeated injection or infusion. Anesth Analg 1992; 74: 420-3.

4 Brull SJ, Connelly NR, Garwood S, Garcia R, Silverman $D G$. Recovery of train-of-four after mivacurium. Anesthesiology 1993; 79: A925.

5 Shanks CA, Fragen RJ, Pemberton D, Katz JA, Risner $M E$. Mivacurium-induced neuromuscular blockade following single bolus doses and with continuous infusion during either balanced or enflurane anesthesia. Anesthesiology 1989; 71: 362-6.

6 Shanks $C A$. Pharmacokinetics of the nondepolarizing neuromuscular relaxants applied to calculation of bolus and infusion dosage regimens. Anesthesiology 1986; 64: 72-86.

7 Naguib M, Abdulatif M, Al-Ghamdi A, Hamo I, Nouheid $\boldsymbol{R}$. Dose-response relationships for edrophonium and neostigmine antagonism of mivacurium-induced neuromuscular block. Br J Anaesth 1993; 71: 709-14.

$8 \mathrm{KaO}$ YJ, Le N, Barker SJ. Neostigmine prolongs profound neuromuscular blockade induced by mivacurium in surgical patients. Anesthesiology 1993; 79: A929.

9 Ferguson A, Egerszegi P, Bevan DR. Neostigmine, pyridostigmine, and edrophonium as antagonists of pancuronium. Anesthesiology 1980; 53: 390-4.

10 Kopman AF, Mallhi MU, Justo MD, Rodricks $P$, Neuman GG. Antagonism of mivacurium-induced neuromuscular blockade in humans. Anesthesiology 1994; 81: 1394-400.

11 Viby-Mogensen J, Jensen NH, Engbaek J, Ording $H$, Skovgaard LT, Chraemmer-Jørgensen B. Tactile and visual evaluation of the response to train-of-four nerve stimulation. Anesthesiology 1985; 63: 440-3.

12 Kitts J, Martineau R, Miller D, Hull $K$, Lindsay $P$, Curran $M$. Evaluation of the peripheral nerve stimulator vs EMG for monitoring neuromuscular block during continuous infusion of atracurium. Can J Anaesth 1993; 40: A56.
13 Bevan DR, Donati F, Kopman AF. Reversal of neuromuscular blockade. Anesthesiology 1992; 77: 785-805.

14 King MJ, Milazkiewicz R, Carli F, Deacock $A R$. Influence of neostigmine on postoperative vomiting. $\mathrm{Br} \mathrm{J}$ Anaesth 1988; 61: 403-6.

15 Kao YJ, Mian T, McDaniel KE, Kleinman S, Arthur J, McCabe HJ. Neuromuscular blockade reversal agents induce postoperative nausea and vomiting. Anesthesiology 1992; 77: A1120.

16 Steegmuiller $H$. On the geographical distribution of pseudocholinesterase variants. Humangenetik 1975; 26: 167-85.

17 Lubin AH, Garry PJ, Owen GM. Sex and population difference in the incidence of a plasma cholinesterase variant. Science 1971; 173: 161-4.

18 Pantuck EJ. Plasma cholinesterase: gene and variations. Anesth Analg 1993; 77: 380-6.

19 Primo-Parmo SL, Greenberg CP, Pantuck EJ, La Du BN. A new variant of human butyrylcholinesterase with reduced affinity for succinylcholine. Anesthesiology 1994; 81: A460. 